\title{
Nitrate, phosphate, and iron limitation of the phytoplankton assemblage in the lagoon of Takapoto Atoll (Tuamotu Archipelago, French Polynesia)
}

\author{
A. Sakka ${ }^{1}$, L. Legendre ${ }^{1, *}$, M. Gosselin ${ }^{2}$, B. LeBlanc ${ }^{1}$, B. Delesalle ${ }^{3}$, N. M. Price ${ }^{4}$ \\ 'Département de biologie, Université Laval, Québec, Québec G1K 7P4, Canada \\ ${ }^{2}$ Département d'océanographie, Université du Québec à Rimouski, 310 Allée des Ursulines, Rimouski, \\ Québec G5L 3A1, Canada \\ ${ }^{3}$ Ecole Pratique des Hautes Etudes, Laboratoire de biologie marine et malacologie, URA CNRS 1453, \\ Université de Perpignan, 66860 Perpignan Cedex, France \\ ${ }^{4}$ Department of Biology, McGill University, 1205 Avenue Dr Penfield, Montreal, Quebec H3A 1B1, Canada
}

\begin{abstract}
Algal blooms sporadically occur in atoll lagoons of the Tuamotu Archipelago (French Polynesia). The present study was conducted in the lagoon of Takapoto Atoll to investigate the roles of $N$, $\mathrm{P}$ and $\mathrm{Fe}$ in controlling the biomass and production of algae. Addition of $\mathrm{P}$ alone had no significant effect on phytoplankton. The NP enrichments resulted in the highest increases of $<3$ and $>3 \mu \mathrm{m}$ chlorophyll a (chl a), algal carbon production, algal abundance (especially the pennate diatom Proboscia alata), and protozoan carbon production. Addition of $\mathrm{N}$ alone also enhanced chl a and algal carbon production, but was less effective than when $N$ was combined with P. Dinoflagellates, which were dominated by Gymnodinium spp., showed the greatest response to the $+\mathrm{N}$ treatment. In one experiment, $\mathrm{Fe}$ addition (with EDTA) significantly enhanced chl $a$ in the $>3 \mu \mathrm{m}$ size fraction, and the net rates of algal and protozoan carbon production. The $+F e$ treatment especially enhanced the abundance of the coccolithophore Acanthoica sp. These results indicate that $\mathrm{N}$ followed by $\mathrm{P}$ limited the biomass and production of small and large algae, and that Fe may have been at times in short supply and limited the large algae. A sudden supply of these nutrients to the lagoon, by natural phenomena, may trigger a phytoplankton outburst and change the taxonomic composition of the algal community. Production and grazing of protozoa may have been indirectly regulated by the availability of $\mathrm{N}, \mathrm{P}$ and $\mathrm{Fe}$, since the quantity of their algal food was controlled by these nutrients.
\end{abstract}

KEY WORDS: Atoll lagoon Phytoplankton - Protozoa - Nutrient limitation · Bioassays

\section{INTRODUCTION}

In oligotrophic temperate and tropical waters, nutrient availability is generally considered to be the main factor affecting phytoplankton growth rates (Dugdale \& Goering 1967, DiTullio et al. 1993), biomass (Dugdale \& Wilkerson 1992, Graziano et al. 1996), and species composition (DiTullio et al. 1993). Which nutrients actually limit algal growth is debated (Smith 1984). In

- Addressee for correspondence.

E-mail: louis.legendre@bio.ulaval.ca general, $\mathrm{N}$ and $\mathrm{P}$ are considered to be the major nutrients that limit phytoplankton net production. Ecosystems with ratios of dissolved inorganic nitrogen to phosphorus less than the average plankton intracellular ratio $(N: P=16: 1)$ are generally considered to be $N$ limited, whereas those with $\mathrm{N}: \mathrm{P}>16: 1$ would be $\mathrm{P}$ limited (Redfield et al. 1963, Heckey \& Kilham 1988).

Recent studies have shown that macronutrients ( $N$, $\mathrm{P}$, and $\mathrm{Sil}$ and trace metals (Fe) may co-limit algal growth and species composition (Martin et al. 1994, Price et al. 1994). The exact role of $\mathrm{Fe}$ in controlling the structure and production of algal assemblages is 
under study. In the equatorial Pacific, experimental additions of Fe to seawater. indicate that the biomass and production of phytoplankton (especially the nanosized cells) are severely limited by $\mathrm{Fe}$ availability (Cullen et al. 1992, Wells et al. 1994, Lindley \& Barber 1998). Although the biomass and production of picophytoplankton are not typically Fe limited (Cullen et al. 1992, Price et al. 1994), recent studies suggest physiological limitation of small phytoplankton by Fe (Behrenfeld et al. 1996, Henley \& Yin 1998). Procaryotic picophytoplankton are capable of specific uptake of ferric iron by excretion of siderophores (Brown \& Trick 1992, Wilhelm \& Trick 1994, Wilhelm et al. 1996). Some cyanobacteria can fix $N_{2}$, which requires much Fe (Rueter et al. 1990, Hutchins et al. 1991). $\mathrm{N}_{2}$-fixing phytoplankton are widespread in tropical and sub-tropical marine environments (Carpenter 1983). A recent laboratory study reported possible Fe limitation of protozoa (Chase \& Price 1997). It follows that understanding the exact effects of Fe enrichment on natural phytoplankton assemblages requires investigating not only the responses of algae, but also those of their grazers (Price et al. 1994, de Baar et al. 1995).

In atoll lagoons and other coral reef systems, macronutrients may limit the growth of some algae. Kinsey \& Domm (1974) did not find significant effects of $N$ and $P$ addition on planktonic activity in the atoll lagoon of One Tree Island (Great Barrier Reef, Australia), but they observed a pronounced increase of the net production of benthic algae. In the same lagoon, Larkum \& Koop (1997) could not find any effect of $\mathrm{N}$ or $\mathrm{P}$ addition on epilithic algae. Smith (1984) proposed that P limits phytoplankton in the lagoon of Canton Atoll (Central Pacific Ocean). In Kaneohe Bay (Hawaii), Laws \& Allen (1996) reported that $N$ is always more limiting than $P$. Recent in vitro nutrient enrichment experiments have shown that $\mathrm{N}$ most frequently limited the growth of phytoplankton in 10 atolls of the Tuamotu Archipelago (French Polynesia, Dufour \& Berland 1999). Concerning micronutrients, Entsch et al. (1983b) reported possible Fe limitation of coral reef primary producers of Davies Reef (Great Barrier Reef).

In recent years, strong phytoplankton blooms occurred sporadically in French Polynesian atoll lagoons, sometimes accompanied by mortality of natural or farmed black-pearl oysters. The present research was conducted within the context of a program that investigated the origins of these algal blooms. The study site was the lagoon of Takapoto Atoll (Tuamotu Archipelago, French Polynesia), which supports large black-pearl oyster farming.

In Takapoto Atoll, there have been several studies on nutrient concentrations, but few have investigated the role of nutrients in controlling the biomass and production of phytoplankton. The lagoon is characterized by low nutrient concentrations $(<0.2 \mu \mathrm{M} \mathrm{NO}$
$<0.1 \mu \mathrm{M} \mathrm{PO} \mathrm{PO}_{4 i}$ Charpy 1996). Our first hypothesis was that phytoplankton there are limited by major nutrients such as $\mathrm{N}$ and/or $\mathrm{P}$ which, when supplied to the system, may trigger algal outbursts. In the Takapoto lagoon, the phytoplankton assemblage is dominated by single-celled cyanobacteria (Charpy et al. 1992, Charpy \& Blanchot 1996). In addition, $\mathrm{N}_{2}$-fixing filamentous cyanobacteria are widely distributed in Polynesian lagoons (Charpy-Roubaud et al. 1997). Because the $\mathrm{Fe}$ requirements of both $\mathrm{N}_{2}$-fixing and singlecelled cyanobacteria are much higher than those of other algae (Price \& Morel 1998), and because oceanic waters contain low concentrations of $\mathrm{Fe}$, we further hypothesized that the large algae in the lagoon are $\mathrm{Fe}$ limited.

The approdch used to test our 2 hypotheses was that of bioassays, with addition of $\mathrm{N}, \mathrm{P}$ and $\mathrm{Fe}$, alone or in combination. During the experiments, we (1) determined changes in chlorophyil a (chl a) biomass in the $<3$ and $>3 \mu \mathrm{m}$ size fractions, (2) estimated the rates of algal and protozoan carbon production, and (3) quantified the responses of the different taxonomic groups of algae.

\section{METHODS}

Characteristics of the study site. Takapoto $\left(14^{\circ} 30^{\prime} \mathrm{S}\right.$, $145^{\circ} 20^{\prime} \mathrm{W}$ ) (Fig. 1) is one of the 75 atolls of the Tuamotu Archipelago. It is almost closed, with a continuous reef rim. Exchanges with the ocean are restricted to the so-called 'hoa', which are narrow and very shallow $(50 \mathrm{~cm}$ deep) breaks in the reef rim where currents are generally weak (Sournia \& Ricard 1976). The lagoon has a surface area of $81 \mathrm{~km}^{2}$ (Andrefouet 1994) and a mean depth of $25 \mathrm{~m}$ (Charpy 1996). Water transparency is such that the euphotic zone extends down to the bottom. Residence time of water in the lagoon is about 4 yr (Sournia \& Ricard 1976). Prevailing winds from the east are considered to be the main forcing factor within the lagoon since tides are negligible (Rougerie 1979). A small village is located at the southern end of the rim. The main economic activity is pearl-oyster farming, which began on a regular basis in 1970 .

Experimental procedure. Five experiments were conducted during April 1996 (BioI-96 and Bioll-96) and 1997 (Biol-97, Bioll-97 and Bioll-97). There were 5 treatments, i.e. additions of $\mathrm{N}$ alone, Fe alone, $\mathrm{P}$ alone, $\mathrm{N}$ and $\mathrm{Fe}$, and $\mathrm{N}$ and $\mathrm{P}$, plus controls (no nutrient addition). Fe was added as $\mathrm{FeCl}_{3}$ solution in 1996, and a FeEDTA complex (1:1) in 1997. The 5 treatments were not included in all experiments. Table 1 summarizes the conditions of each experiment. In all cases, water samples were collected at 1 station in the lagoon ( $\operatorname{Stn} 9$, 
Fig. 1), which was considered to be representative of mean lagoon conditions. Sampling was at 06:00 h. To avoid contamination, acid-cleaned and Milli-Q-rinsed 2 l polycarbonate bottles were filled with lagoon water at the sampling station by snorkeling divers. The bottles were held beneath the surface and the cap was removed to allow water to flow in. The bottles were kept in isothermal containers during transfer to the laboratory, where they were amended with different nutrients. All stock solutions were previously eluted through a Chelex-100 column to remove trace metals (Price et al. 1989). The bottles were placed inside Zip-lock plastic bags to avoid contamination, and incubated in situ at $2 \mathrm{~m}$ depth for 4 or $5 \mathrm{~d}$. After 2,4 , and $5 \mathrm{~d}$ of incubation, 2 or 3 bottles for each nutrient treatment and the control were removed. Each bottle was subsampled for determination of nutrients $\left(\mathrm{NO}_{2}+\mathrm{NO}_{3}\right.$ $\mathrm{PO}_{4}$, and $\left.\mathrm{Si}(\mathrm{OH})_{4}\right)$, chl $a_{4}$ and cell numbers. At the beginning of each incubation, lagoon water samples were taken to determine the same variables as on the treatments. For all nutrient treatments, the bottle cleaning, enrichment and subsampling were conducted inside a class 100 laminar-flow hood to avoid contamination.

Laboratory analyses. Subsamples for nutrients were filtered through Whatman GF/F (glass-fiber) filters in a Sartorius holder mounted on a syringe. The filtrate was kept frozen in liquid nitrogen in $2 \mathrm{ml}$ plastic cryovials. Analyses were done on an Alpkem AutoAnalyzer, following the methods described in Parsons et al. (1984).

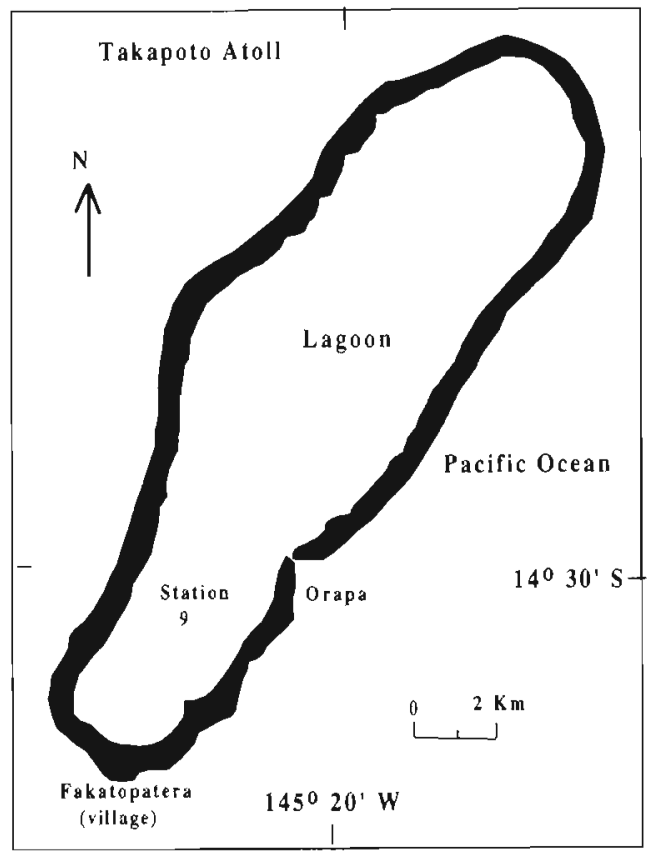

Fig. 1 Takapoto Atoll, French Polynesia: location of the sampling station

For chl a, 1000 or $1500 \mathrm{ml}$ of water were sequentially filtered on $3.0,1.0$, and $0.2 \mu \mathrm{m}$ polycarbonate Nuclepore filters. All filirations were performed under low vacuum pressure ( $<100 \mathrm{~mm} \mathrm{Hg}$ ) as recommended by Goldman \& Dennett (1985). Pigments were extracted in $90 \%$ acetone for at least $30 \mathrm{~h}$ in the dark at $0^{\circ} \mathrm{C}$, and

Table 1. General information on the nutrient enrichment bioassays

\begin{tabular}{|c|c|c|c|c|}
\hline Expt & Starting date & Days sampled & Treatments (final conc.) & No. replicates \\
\hline Biol-96 & 18 Apr 1996 & $0,2,4$ and $5 \mathrm{~d}$ & $\begin{array}{l}\text { - Control } \\
\text { - } 20 \mu \mathrm{M} \mathrm{NaNO} \\
\text { - } 2 \mathrm{nMFeCl}_{3} \\
\text { - } 2 \mathrm{nMFeCl}_{3}+20 \mu \mathrm{M} \mathrm{NaNO}\end{array}$ & $\begin{array}{l}2 \\
2 \\
2 \\
2\end{array}$ \\
\hline Bioll-96 & 26 Apr 1996 & $0,2,4$ and $5 \mathrm{~d}$ & $\begin{array}{l}\text { - Control } \\
\text { - } 20 \mu \mathrm{M} \mathrm{NaNO}_{3} \\
\text { - } 5 \mathrm{nMFeCl}_{3} \\
\text { - } 5 \mathrm{nMFeCl}_{3}+20 \mu \mathrm{M} \mathrm{NaNO}_{3}\end{array}$ & $\begin{array}{l}2 \\
2 \\
2 \\
2\end{array}$ \\
\hline BioI-97 & 2 Apr 1997 & $0,2,4$ and $5 \mathrm{~d}$ & $\begin{array}{l}\text { - Control } \\
\text { - } 20 \mu \mathrm{M} \mathrm{NaNO}_{3} \\
\text { - } 5 \text { nM FeEDTA }(1: 1) \\
\text { - } 5 \text { nM FeEDTA }(1: 1)+20 \mu \mathrm{M} \mathrm{NaNO}_{3}\end{array}$ & $\begin{array}{l}3 \\
3 \\
3 \\
3\end{array}$ \\
\hline Bioll-97 & 11 Apr 1997 & $0,2,4$ and $5 \mathrm{~d}$ & $\begin{array}{l}\text { - Control } \\
\text { - } 20 \mu \mathrm{M} \mathrm{NaNO} \\
\text { - } 1.5 \mu \mathrm{MPO}_{4} \\
-1.5 \mu \mathrm{MPO}_{4}+20 \mu \mathrm{M} \mathrm{NaNO}_{3}\end{array}$ & $\begin{array}{l}3 \\
3 \\
3 \\
3\end{array}$ \\
\hline Biolli-97 & 18 Apr 1997 & $0,2,3$ and $4 \mathrm{~d}$ & $\begin{array}{l}\text { - Control } \\
\text { - } 20 \mu \mathrm{M} \mathrm{NaNO} \\
\text { - } 1.5 \mu \mathrm{M} \mathrm{PO}_{4} \\
-1.5 \mu \mathrm{M} \mathrm{PO}_{4}+20 \mu \mathrm{M} \mathrm{NaNO}\end{array}$ & $\begin{array}{l}3 \\
3 \\
3 \\
3\end{array}$ \\
\hline
\end{tabular}


analyzed using a Turner Fluorometer model 112 according to the method described in Parsons et al. (1984).

For the identification and enumeration of $>3 \mu \mathrm{m}$ algae and protozoa, $250 \mathrm{ml}$ subsamples were fixed with $1 \%$ (final concentration) of $0.22 \mu \mathrm{m}$ prefiltered formaldehyde. Counting was done under the inverted microscope (Utermöhl 1931, Lund et al. 1958). For each sample, 200 to 300 cells were counted.

Samples $(40 \mathrm{ml})$ for enumeration of cyanobacteria and eucaryotic $<3 \mu \mathrm{m}$ phytoplankton were preserved in $0.22 \mu \mathrm{m}$ prefiltered formaldehyde (final concentration: $0.2 \%$ ). These samples were stored for at least $1 \mathrm{~h}$ in the dark at $5^{\circ} \mathrm{C}$ before subsequent processing (Hall 1991). Subsamples $(10 \mathrm{ml})$ were filtered onto black polycarbonate Nuclepore filters $(0.22 \mu \mathrm{m}, 25 \mathrm{~mm})$ using low vacuum pressure $(<5 \mathrm{~mm} \mathrm{Hg})$. The filters were mounted on slides using low fluorescence immersion oil and frozen immediately. Cells were enumerated within 5 wk of sampling using a Leitz Dialux 22 epifluorescence microscope $(100 \times$ Leitz Fluotar objective), as described in MacIsaac \& Stockner (1993). Phycoerythrin-rich and chlorophyll-rich cells were enumerated using a BP 54 6/20 excitation filter for green wavelengths (code 513416 ) and a BP 390-490 for blue wavelengths (code 513460 ). The former cells fluoresce red-orange when excited by green light, and the latter appear dull red under blue excitation. On each filter, 600 cells were counted from 30 random fields.

Calculations. In order to determine the cell biovolumes of phytoplankton and protozoa, the length and width of cells were measured at $1000 \times$ using an ocular micrometer. Standard geometric shapes were applied, and carbon biomasses were calculated using conversion factors of $0.25 \mathrm{pg} \mathrm{C} \mathrm{\mu m}^{-3}$ for cyanobacteria (Kana \& Glibert 1987), $0.22 \mathrm{pg} \mathrm{C} \mathrm{\mu m}^{-3}$ for eucaryotic phytoplankton (Booth 1988), $0.15 \mathrm{pg} \mathrm{C} \mathrm{m}^{-3}$ for hetero- trophic flagellates (Sheldon et al. 1986), and 0.19 pg $\mathrm{C} \mu \mathrm{m}^{-3}$ for ciliates (Putt \& Stoecker 1989).

Net rates of carbon production for algae $(\mu)$ and protozoa were calculated from linear regressions of natural log of carbon biomass on time. The carbon production rates for protozoa were divided by their gross growth efficiency $\left(k_{1}=0.31\right.$; Rassoulzadegan 1982) to determine the ingested phytoplankton carbon, i.e. the grazing rate of protozoa on algae $(g)$. The grazing rate of protozoa was added to $\mu$ to obtain the gross rate of algal carbon production $\left(\mu^{\prime}=\mu+g\right)$.

Nutrient consumption rates were the slopes of the linear regressions of nutrient concentrations in the bottles during the course of the experiments. The significance of slopes was tested using the Student's $t$-test.

Statistical analyses. Two-way analysis of variance (ANOVA) was used for comparing average values ( $\mathrm{Zar}$ 1984). When there was a significant interaction between sampling time and tredments, we used an ANOVA with repeated measures. The ANOVA was followed by Dunnett's a posteriori contrast test, to identify which treatment was significantly different from the control. No transformation of the data was required since the normality of distribution (Shapiro-Wilk's test) and the homogeneity of variance (test of Bartlett-Box) (Zar 1984) were respected.

\section{RESULTS}

\section{Effects of nutrient enrichments on chl a biomass}

Table 2 gives the chl a concentrations of the $<3$ and $>3 \mu \mathrm{m}$ size fractions at the beginning of each experiment. The responses of chl a biomass to the $+\mathrm{N}$ treatment varied over the 5 experiments. Among all $\mathrm{N}$ enriched bioassays, only BioI-96 and Biol-97 showed

Table 2. Concentrations of nutrients $\left(\mathrm{PO}_{4} ; \mathrm{Si}(\mathrm{OH})_{4}\right)$, chl $a$ in the $>3 \mu \mathrm{m}$ and $<3 \mu \mathrm{m}$ size fractions, $>3 \mu \mathrm{m}$ algae, $<3 \mu \mathrm{m}$ algae (cyanobacteria and eucaryotic algae), and protozoa at the beginning of each experiment in 1996 (Biol-96 and Bioll-96) and 1997 (BioI-97, Bioll-97, and BiollI-97); nd: not determined. Averages \pm SD

\begin{tabular}{|c|c|c|c|c|c|}
\hline & Biol-96 & Bioll-96 & Biol-97 & Biol-97 & BiollI-97 \\
\hline \multicolumn{6}{|l|}{ Nutrient $(\mu \mathrm{M})$} \\
\hline $\mathrm{PO}_{4}$ & $0.17 \pm 0.00$ & $0.22 \pm 0.00$ & $0.12 \pm 0.05$ & $0.27 \pm 0.03$ & $0.13 \pm 0.02$ \\
\hline $\mathrm{Si}(\mathrm{OH})_{4}$ & nd & nd & $0.14 \pm 0.04$ & $0.10 \pm 0.05$ & $0.13 \pm 0.01$ \\
\hline \multicolumn{6}{|l|}{ 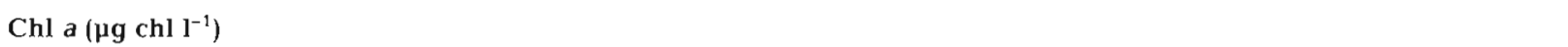 } \\
\hline$>3 \mu \mathrm{m}$ size fraction & $0.04 \pm 0.02$ & $0.05 \pm 0.00$ & $0.04 \pm 0.03$ & $0.06 \pm 0.00$ & $0.06 \pm 0.00$ \\
\hline$<3 \mu \mathrm{m}$ size fraction & $0.15 \pm 0.00$ & $0.15 \pm 0.00$ & $0.23 \pm 0.13$ & $0.19 \pm 0.01$ & $0.16 \pm 0.02$ \\
\hline \multicolumn{6}{|l|}{ Cell numbers } \\
\hline$>3 \mu \mathrm{m}$ algae $\left(10^{6}\right.$ cells $\left.\mathrm{l}^{-1}\right)$ & $0.35 \pm 0.07$ & $0.21 \pm 0.05$ & $0.24 \pm 0.00$ & $0.55 \pm 0.00$ & $0.30 \pm 0.02$ \\
\hline$<3 \mu \mathrm{m}$ algae $\left(10^{8}\right.$ cells $\left.\mathrm{l}^{-1}\right)$ & $0.99 \pm 0.03$ & $0.88 \pm 0.02$ & $0.89 \pm 0.05$ & $0.57 \pm 0.00$ & $0.79 \pm 0.12$ \\
\hline Protozoa $\left(10^{5}\right.$ cells $\left.1^{-1}\right\}$ & $0.68 \pm 0.05$ & $0.57 \pm 0.03$ & $0.52 \pm 0.05$ & $0.76 \pm 0.00$ & $0.80 \pm 0.00$ \\
\hline
\end{tabular}


Fig. 2. Changes relative to the controls in the $<3 \mu \mathrm{m}$ and $>3 \mu \mathrm{m}$ chl a for the $(a, b)+N(c, d)$ $+P$, and $(e, f)+N P$ treatments during different experiments (averages $\pm \mathrm{SD}$ )

significant enhancement (relative to the controls) of the $<3$ and $>3 \mu \mathrm{m}$ chl a concentrations (Fig. 2a,b). In the $+\mathrm{P}$ treatments (Bioll-97 and Biolli-97), chl a for the 2 size fractions was similar to the controls in all cases (Fig. 2c, d). In contrast, the enrichments with combined $\mathrm{N}$ and $\mathrm{P}$ resulted in the highest increases of chl $a$ in the small and large size fractions, i.e. $>5$ times relative to the controls (Fig. 2e,f).

The addition of Fe (Biol-96 and BiolI-96) had no significant effect on either the $<3$ or $>3 \mu \mathrm{m}$ chl a (Fig. 3a, b) in 1996. In the 1997 experiment (Biol-97), the $>3 \mu \mathrm{m}$ chl a increased up to 4 times relative to the control (Fig. 3b), which did not occur for the $<3 \mu \mathrm{m}$ size fraction (Fig. 3a). In the Biol-96 and BioI-97+NFe treatments, the $<3 \mu \mathrm{m}$ chl $a$ increased significantly relative to the control (Fig. 3c), as it did with the $N$ enrichment (Fig. 2a). The $>3 \mu \mathrm{m}$ chl a increased in the Biol-96 +NFe enrichment (Fig. 3d), as it did in the $+\mathrm{N}$ treatment (Fig. 2b). In the Biol-97 $+\mathrm{NFe}$ treatment, the $>3 \mu \mathrm{m}$ chl $a$ increased (Fig. 3d), as it did in both the $+\mathrm{N}$ and $+\mathrm{Fe}$ treatments (Figs. 2b \& 3b).
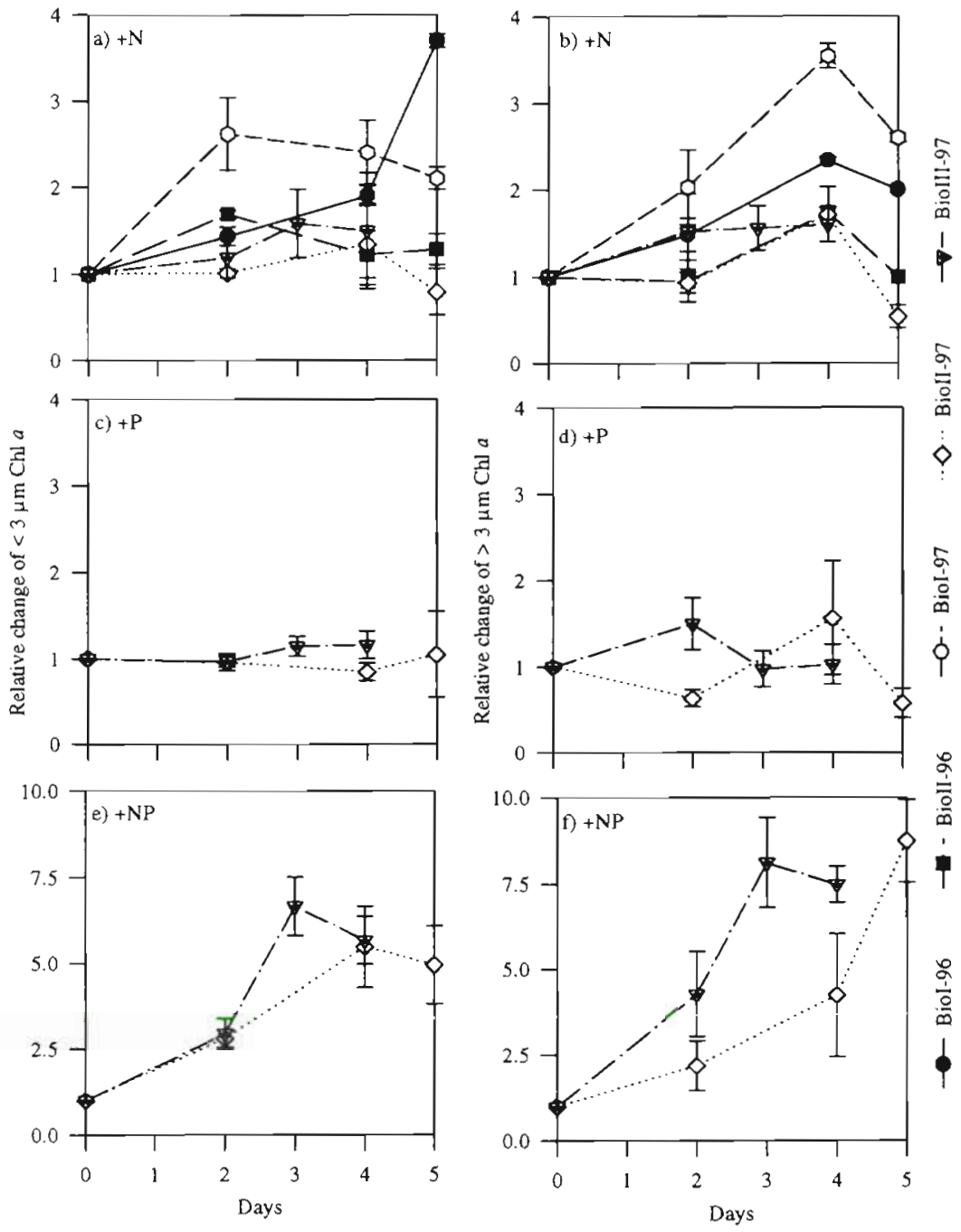
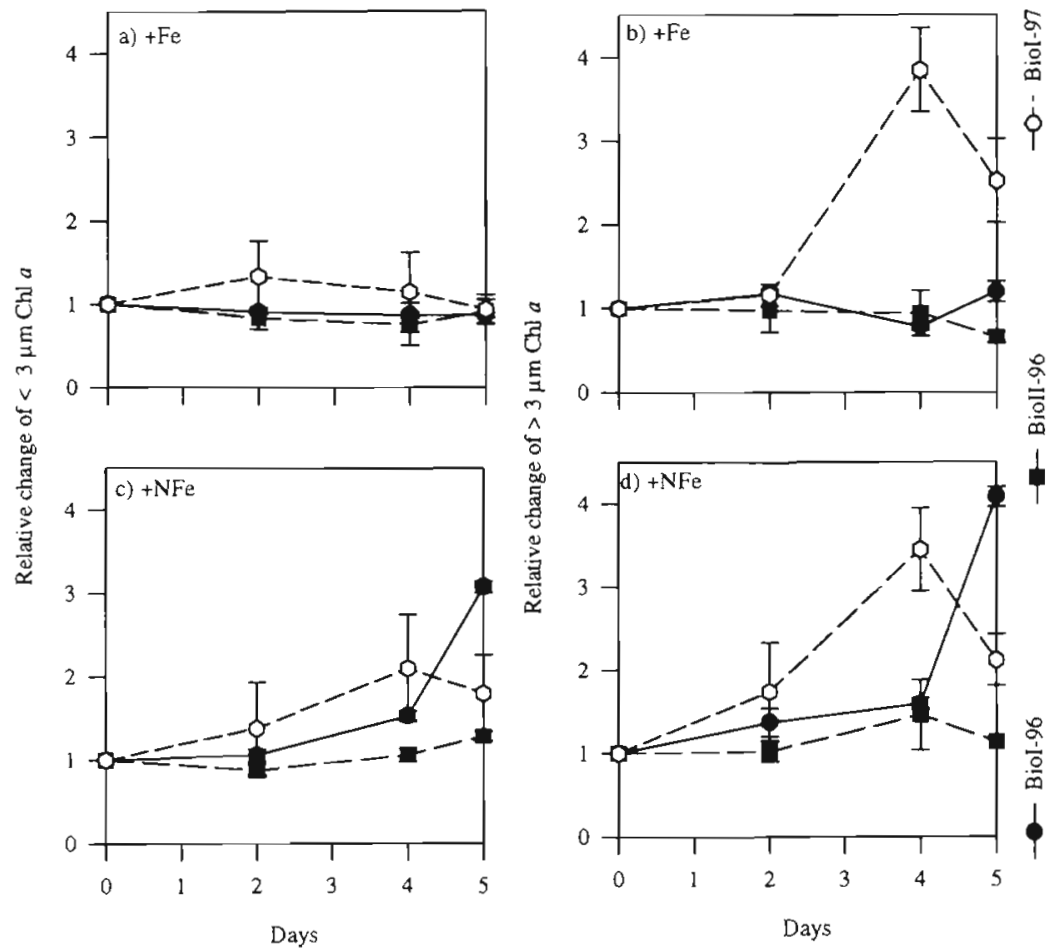

\section{Effects of nutrient enrichments on algal and protozoan carbon production}

Table 3 summarizes the rates of algal and protozoan carbon production, and the grazing rates for each experimental treatment. The $\mathrm{N}$ enrichments enhanced the carbon biomass of algae in the Biol-96 and Biol-97 assays only. During these 2 experiments, the gross rates of algal carbon production were higher in the $+\mathrm{N}$ treatments than in the controls. During Biol-96, the protozoan grazing rate also increased, so that the net rate of algal carbon production was not dif-

Fig. 3. Changes relative to the controls in the $<3 \mu \mathrm{m}$ and $>3 \mu \mathrm{m}$ chl a for the $(\mathrm{a}, \mathrm{b})+\mathrm{Fe}$, and (c, d) $+\mathrm{NFe}$ treatments during different experiments (averages $\pm \mathrm{SD}$ ) 
Table 3 . Gross and net rates of algal carbon production $\left(\mathrm{d}^{-1}\right)$, rates of protozoan carbon production $\left(\mathrm{d}^{-1}\right)$, and grazing rates $\left(\mathrm{d}^{-1}\right)$ in different treatments during each exper-iment. Averages \pm SD. Values significantly higher than the control $(p<0.05)$ are in bold type

\begin{tabular}{|c|c|c|c|c|c|c|}
\hline Expt & Control & $+\mathrm{N}$ & $+\mathrm{Fe}$ & $\begin{array}{c}\text { Enrichment } \\
+\mathrm{NFe}\end{array}$ & $+\mathrm{P}$ & $+\mathrm{NP}$ \\
\hline \multicolumn{7}{|l|}{ BioI-96 } \\
\hline Net rates of algal carbon production $(\mu)$ & $0.04 \pm 0.00$ & $0.05 \pm 0.01$ & $0.05 \pm 0.00$ & $0.05 \pm 0.01$ & & \\
\hline Gross rates of algal carbon production $\left(\mu^{\prime}\right)$ & $0.69 \pm 0.08$ & $1.32 \pm 0.02$ & $0.57 \pm 0.00$ & $1.15 \pm 0.02$ & & \\
\hline Rates of protozoan carbon production & $0.19 \pm 0.02$ & $\mathbf{0 . 3 8} \pm 0.00$ & $0.15 \pm 0.00$ & $0.33 \pm 0.00$ & & \\
\hline Grazing rate $(g)$ & $0.65 \pm 0.07$ & $1.27 \pm 0.00$ & $0.51 \pm 0.00$ & $1.09 \pm 0.00$ & & \\
\hline \multicolumn{7}{|l|}{ Bioll-96 } \\
\hline Net rates of algal carbon production $(\mu)$ & $0.01 \pm 0.00$ & $0.01 \pm 0.02$ & $0.00 \pm 0.01$ & $0.00 \pm 0.01$ & & \\
\hline Gross rates of algal carbon production $\left(\mu^{\prime}\right)$ & $2.34 \pm 0.16$ & $2.00 \pm 0.14$ & $1.69 \pm 0.07$ & $1.94 \pm 0.02$ & & \\
\hline Rates of protozoan carbon production & $0.70 \pm 0.04$ & $0.59 \pm 0.06$ & $0.50 \pm 0.02$ & $0.58 \pm 0.01$ & & \\
\hline Grazing rate $(g)$ & $2.33 \pm 0.16$ & $1.99 \pm 0.20$ & $1.68 \pm 0.07$ & $1.93 \pm 0.05$ & & \\
\hline BioI-97 & & & $(+\mathrm{EDTA})$ & $(+$ EDTA $)$ & & \\
\hline Net rates of algal carbon production $(\mu)$ & $-0.21 \pm 0.01$ & $0.00 \pm 0.00$ & $0.07 \pm 0.01$ & $0.08 \pm 0.00$ & & \\
\hline Gross rates of aigai carbun production $\left(\mu^{\prime}\right)$ & $1.25 \pm 0.03$ & $1.85 \pm 0.09$ & $3.38 \pm 0.12$ & $3.16 \pm 0.34$ & & \\
\hline Rates of protozoan carbon production & $0.44 \pm 0.01$ & $0.55 \pm 0.01$ & $0.99 \pm 0.02$ & $0.92 \pm 0.08$ & & \\
\hline Grazing rate $(g)$ & $1.46 \pm 0.03$ & $1.85 \pm 0.06$ & $3.30 \pm 0.06$ & $3.07 \pm 0.25$ & & \\
\hline \multicolumn{7}{|l|}{ BiolI-97 } \\
\hline Net rates of algal carbon production $(\mu)$ & $-0.14 \pm 0.00$ & $-0.15 \pm 0.00$ & & & $-0.13 \pm 0.03$ & $0.19 \pm 0.02$ \\
\hline Gross rates of algal carbon production $\left(\mu^{\prime}\right)$ & $0.42 \pm 0.01$ & $0.33 \pm 0.03$ & & & $0.29 \pm 0.02$ & $2.28 \pm 0.18$ \\
\hline Rates of protozoan carbon production & $0.17 \pm 0.00$ & $0.14 \pm 0.01$ & & & $0.13 \pm 0.08$ & $0.62 \pm 0.07$ \\
\hline Grazing rate $(g)$ & $0.57 \pm 0.02$ & $0.48 \pm 0.05$ & & & $0.43 \pm 0.26$ & $2.08 \pm 0.09$ \\
\hline \multicolumn{7}{|l|}{ BioIII-97 } \\
\hline Net rates of algal carbon production $(\mu)$ & $0.10 \pm 0.05$ & $0.13 \pm 0.05$ & & & $0.11 \pm 0.03$ & $\mathbf{0 . 4 9} \pm 0.02$ \\
\hline Gross rates of algal carbon production $\left(\mu^{\prime}\right)$ & $0.81 \pm 0.11$ & $0.65 \pm 0.13$ & & & $0.76 \pm 0.02$ & $1.99 \pm 0.10$ \\
\hline Rates of protozoan carbon production & $0.21 \pm 0.00$ & $0.15 \pm 0.02$ & & & $0.19 \pm 0.00$ & $0.45 \pm 0.03$ \\
\hline Grazing rate $(g)$ & $0.71 \pm 0.02$ & $0.52 \pm 0.07$ & & & $0.65 \pm 0.01$ & $1.50 \pm 0.11$ \\
\hline
\end{tabular}

ferent from the control. In contrast, during BioI-97, the grazing rate of protozooplankton was not affected by the $+\mathrm{N}$ treatment, so that the net rate of algal carbon production was enhanced relative to the control. As observed for chl $a$, the addition of $\mathrm{P}$ alone had no effects on the carbon biomasses of algae or their grazers. The combined addition of $\mathrm{N}$ and $\mathrm{P}$ resulted in the highest increases of the net and gross rates of algal carbon production among all experiments. These were at least 2.5 times higher than in the controls or the $+\mathrm{N}$ treatments. The growth and grazing rates of protozod were also enhanced during Bioll-97 and BiolII -97 by factors $\geq 2$.

The + Fe treatments did not affect the rates of phytoplankton carbon production or the protozoan grazing rates in the 1996 experiments (Biol-96 and BioII-96). In contrast, the addition of Fe in Biol-97 increased the rates of algal carbon production and protozoan grazing by 2.5 times relative to the control. In the Biol-96 and Bioll-96 experiments, the rates of algal carbon production and protozoan grazing responded to the $+\mathrm{NFe}$ treatments in the same way as in the $+\mathrm{N}$ treatments whereas, in the Biol $-97+\mathrm{NFe}$ treatment, the responses of phytoplankton carbon production and protozoo- plankton grazing were similar to those observed in the + Fe enrichment.

\section{Effects of nutrient enrichments on the $>3 \mu \mathrm{m}$ algal assemblage}

Table 2 gives the numbers of $>3 \mu \mathrm{m}$ algae at the beginning of each experiment. The abundances of the various taxonomic groups increased significantly relative to the controls in the $+\mathrm{N},+\mathrm{Fe}$, and $+\mathrm{NFe}$ treatments for the Biol-97 experiment only (Fig. 4). Dinoflagellates (dominated by Gymnodinium spp.) showed the strongest response to the $\mathrm{N}$ enrichment, being 5 times more abundant than in the control at the end of the incubation (Fig. 4a,b). The abundance of chlorophyceae (mostly represented by Nannochloropsis sp. and Chlamydomonas sp.) also increased significantly in the $+\mathrm{N}$ treatment, but the coccolithophores did not (Fig. 4a,b).

The 3 taxonomic groups and their dominant genera showed no response to the Fe addition, alone or combined with $\mathrm{N}$, in the 1996 experiments (data not shown). In the $1997+\mathrm{Fe}$ treatment, cell numbers for the 

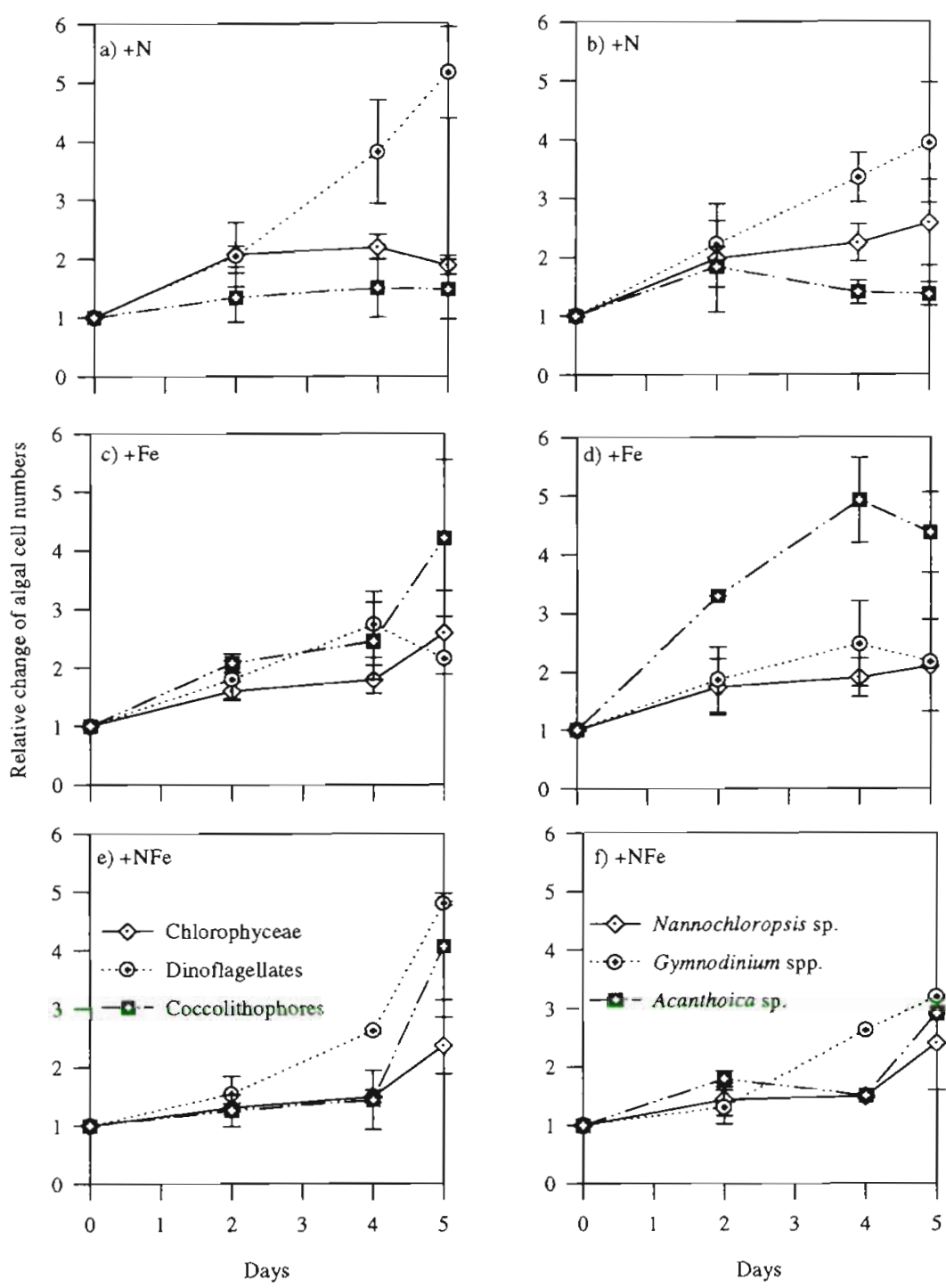

Fig. 4. Changes relative to the controls in cell numbers of chlorophyceae, dinoflagellates and coccolithophores, and various algal taxa for the $(a, b)+N$ $(c, d)+F e$, and $(e, f)+N F e$ treatments during the BioI-97 experiment (averages $\pm \mathrm{SD}$ )

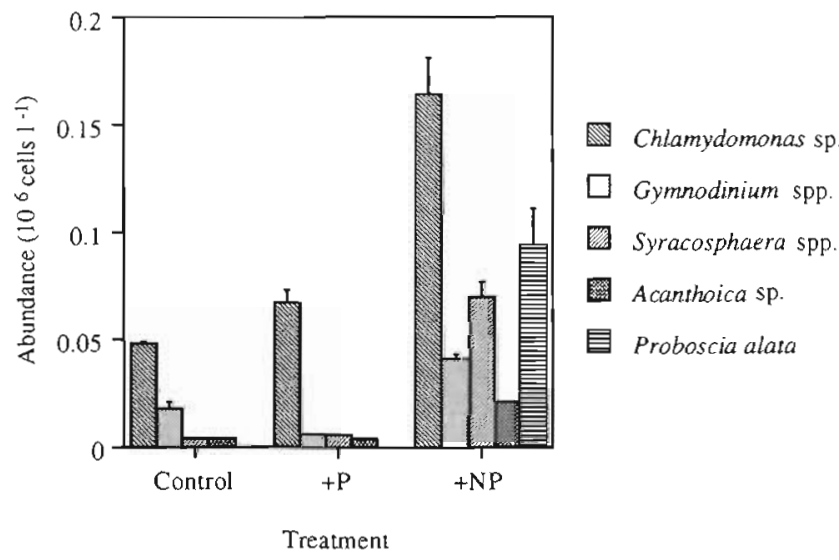

3 groups (Fig. 4c) and the $>3 \mu \mathrm{m}$ chl $a$ (Fig. 3b) showed significant enhancement relative to the control. The addition of $\mathrm{Fe}$ especially favored the growth of coccolithophores (Fig. 4c). In the +Fe treatment, the cocco-lithophore Acanthoica sp. was almost 5 times more abundant than in the control after $4 \mathrm{~d}$ of incubation (Fig. 4d). The growth of chlorophyceae and dinoflagellates was also higher than in the control (Fig. 4c). The abundance of the dominant genus in each algal group, i.e. Nannochloropsis sp. and Gymnodinium spp., doubled relative to the control (Fig. 4d).

The abundance of coccolithophores did not respond to the $+\mathrm{N}$ treatment (Fig. 4a) but, when $\mathrm{Fe}$ was combined with $N$, the growth of this group significantly increased, with Acanthoica sp. reaching a value almost 3 times higher than in the control (Fig. $4 \mathrm{e}$ ). The growth of chlorophyceae and dinoflagellates in the $1997+$ NFe treatment exceeded that of the control (Fig. $4 \mathrm{e}$ ), as in the $+\mathrm{N}$ and + Fe treatments (Fig. 4a,c).

Fig. 5 shows the abundance of different genera in the control and the $+P$ and +NP treatments, after $5 \mathrm{~d}$ of incubation in the Bioll-97 experiment. In bottles enriched with P only, the abundances of the 3 taxonomic groups and their dominant genera were similar to that of the control. In contrast, the whole algal assemblage responded positively to the $+\mathrm{NP}$ treatment. In the other treatments $(+N,+P,+F e$, and $+\mathrm{NFe}$, the composition of the algal community remained the same for the chlorophyceae, dinoflagellates, and coccolithophores. In the +NP treatment, the pennate diatom Proboscia alata was often observed. This diatom was not detected in the control or other treatments (data not shown). At the end of the BioII-97 incubation, the abundance of chlorophyceae Chlamydomonas sp. tripled in the +NP treatment, and that of dinoflagellate Gymnodinium spp. doubled.

Fig. 5. Abundances of various algal taxa in the controls, and the $+\mathrm{P}$ and $+\mathrm{NP}$ treatments at the end of $5 \mathrm{~d}$ incubations in the Bioll-97 experiment (averages \pm SD). Pennate diatom Proboscia alata was not detected in the controls and the $+P$ treatment 
Concerning coccolithophores, the numbers of Syracosphaera sp. and Acanthoica sp. increased nearly 15-fold and 5-fold, respectively.

\section{Effects of nutrient enrichments on the $<3 \mu \mathrm{m}$ algal assemblage}

The numbers of $<3 \mu \mathrm{m}$ phytoplankton (cyanobacteria and eucaryotic algae) at the beginning of each experiment are given in Table 2. The most significant increase in $<3 \mu \mathrm{m}$ algal cell numbers, relative to the controls, occurred in the +NP treatment (Fig. 6e). This increase was observed for both eucaryotic algae and cyanobacteria. The latter are mostly dominated by the genus Synechococcus (Charpy \& Blanchot 1996). The other treatments displayed only small changes relative to the controls (Fig. 6a to d). In most experiments, the composition of the $<3 \mu \mathrm{m}$ phytoplankton community was unaffected by the treatments, and dominated by cyanobacteria (Table 4). A major shift in the $<3 \mu \mathrm{m}$ algal assemblage was observed when $\mathrm{Fe}$ was added in 1997 (Biol-97), alone or combined with $\mathrm{N}(+\mathrm{NFe})$, i.e the contribution of eucaryotes to the $<3 \mu \mathrm{m}$ algae was almost twice as high as in the control (Table 4).

\section{Effects of nutrient enrichments on the nutrient consumption rates}

The concentrations of $\mathrm{PO}_{4}$ and $\mathrm{Si}(\mathrm{OH})_{4}$ at the beginning of each experiment are given in Table 2 . The $\mathrm{NO}_{2}+\mathrm{NO}_{3}$ concentrations for 1996 and 1997 and the $\mathrm{Si}(\mathrm{OH})_{4}$ concentrations for 1996 are not used because of technical problems during analysis. The consumption rates of $\mathrm{PO}_{4}$ increased in the $+\mathrm{P}$ treatment (Table 5), without a corresponding response of phytoplankton (Figs. 2c, d \& 5, Table 3). The highest increases of the $\mathrm{PO}_{4}$ consumption rate were observed in the +NP treatments (Table 5). In most treatments, the consumption rates of $\mathrm{Si}(\mathrm{OH})_{4}$ were not significantly different from the controls (Table 5), except in the Bioll-97 experiment, where the diatom Proboscia alata often occurred (Fig. 5).

\section{DISCUSSION}

\section{Effects of macronutrient enrichments}

The lagoon of Takapoto Atoll is an extremely oligotrophic water body, where the algal biomass does not exceed $0.3 \mu \mathrm{g} \mathrm{chl} \mathrm{a} \mathrm{l}^{-1}$ (Table 2). Our results show that the addition of $\mathrm{N}$ and $\mathrm{P}$ together significantly stimulated the carbon production of both small and large phytoplankton. The strongest increases relative to the controls in chl a (Fig. 2e,f) and numbers of the $>3$ and $<3 \mu \mathrm{m}$ algae (Figs. $5 \& 6 \mathrm{e}$ ) occurred in the +NP treatments. Moreover, the highest gross rates of algal carbon production occurred in the +NP treatment (Table 3). This trend coincides with the enhancement of $\mathrm{PO}_{4}$ consumption rates (Table 5 ). These results
Fig. 6. Changes in the $<3 \mu \mathrm{m}$ phytoplankton cell numbers, relative to the controls, for the (a) $+\mathrm{N}$, (b) $+\mathrm{Fe}_{\text {, }}$ (c) $+\mathrm{NFe},(\mathrm{d})+\mathrm{P}$, and (e) $+\mathrm{N}$ treatments during different experiment (averages $\pm \mathrm{SD}$ ) 
support our first hypothesis that the biomasses of small and large algae in the lagoon are limited by major nutrients.

The present study shows that the addition of $\mathrm{N}$ and $\mathrm{P}$ together had a great effect on the taxonomic composition of large phytoplankton. In all experiments, the most drastic shift in the algal assemblage occurred in the $+N P$ treatment, i.e. the addition of $N$ and $P$ in combination enhanced not only the cell numbers of chlorophyceae, dinoflagellates and coccolithophores, but also of diatoms. In the +NP treatment (Bioll-97), the pennate diatom Proboscia alata was often observed
(Fig. 5), and there was an increase in the consumption rate of $\mathrm{Si}(\mathrm{OH})_{4}($ Table 5). P. alata has a weakly silicified frustule, so that it requires less silicium than heavily silicified taxa. Since silicate concentrations in the lagoon are very low (Table 2), it is likely that the +NP treatment favored the growth of $P$. alata, but not that of other diatoms because these were severely limited not only by $\mathrm{N}$ and P but also Si. Riegman et al. (1996) showed that diatoms have a strong capability of outcompeting other taxa only when silicate is in excess. Blooms of $P$. alata were previously observed in the lagoons of Manihi and Amanu Atolls (Tuamotu Archi-

Table 4 . Contributions $(\%)$ of cyanobacteria and eucaryotic algae to the $<3 \mu \mathrm{m}$ phytoplankton carbon biomass in the various treatments during each experiment. Values are averages over all days of incubation $( \pm \mathrm{SD})$. Values significantly higher than the control $(p<0.05)$ are in bold type

\begin{tabular}{|c|c|c|c|c|c|c|}
\hline Expt & Control & $+\mathrm{N}$ & $+\mathrm{Fe}$ & $\begin{array}{c}\text { Enrichment } \\
+\mathrm{NFe}\end{array}$ & $+\mathrm{P}$ & $+\mathrm{NP}$ \\
\hline \multicolumn{7}{|l|}{ BioI-96 } \\
\hline Cyanobacteria & $66 \pm 0$ & $57 \pm 2$ & $66 \pm 1$ & $60 \pm 2$ & & \\
\hline Eucaryotic algae & $34 \pm 0$ & $43 \pm 1$ & $34 \pm 1$ & $40 \pm 1$ & & \\
\hline \multicolumn{7}{|l|}{ BioII-96 } \\
\hline Cyanobacteria & $67 \pm 2$ & $70 \pm 2$ & $72 \pm 3$ & $70 \pm 3$ & & \\
\hline Eucaryotic algae & $33 \pm 2$ & $30 \pm 2$ & $28 \pm 2$ & $30 \pm 3$ & & \\
\hline Biol-97 & & & $(+\mathrm{EDTA})$ & $(+$ EDTA $)$ & & \\
\hline Cyanobacteria & $69 \pm 2$ & $69 \pm 3$ & $34 \pm 1$ & $40 \pm 1$ & & \\
\hline Eucaryotic algae & $31 \pm 2$ & $31 \pm 3$ & $66 \pm 1$ & $60 \pm 1$ & & \\
\hline \multicolumn{7}{|l|}{ Bioll-97 } \\
\hline Cyanobacteria & $57 \pm 5$ & $56 \pm 4$ & & & $52 \pm 5$ & $54 \pm 3$ \\
\hline Eucaryotic algae & $42+5$ & $43 \pm 4$ & & & $48 \pm 5$ & $46 \pm 3$ \\
\hline \multicolumn{7}{|l|}{ BiolII-97 } \\
\hline Cyanobacteria & $52 \pm 3$ & $55 \pm 4$ & & & $52 \pm 3$ & $53 \pm 2$ \\
\hline Eucaryotic algae & $48 \pm 3$ & $55 \pm 4$ & & & $48 \pm 3$ & $47 \pm 3$ \\
\hline
\end{tabular}

Table 5. Consumption rates $\left(\mu \mathrm{M} \mathrm{d} \mathrm{d}^{-1}\right)$ of nutrients $\left(\mathrm{PO}_{4} \mathrm{Si}(\mathrm{OH})_{4}\right)$ in different treatments during each experiment. Values significantly higher than the control $(p<0.05)$ are in bold type. nd: not determined

\begin{tabular}{|c|c|c|c|c|c|c|}
\hline Expt & Control & $+N$ & $+\mathrm{Fe}$ & $\begin{array}{c}\text { Enrichment } \\
+\mathrm{NFe}\end{array}$ & $+P$ & $+\mathrm{NP}$ \\
\hline \multicolumn{7}{|l|}{ Biol-96 } \\
\hline $\mathrm{PO}_{4}$ & 0.01 & 0.01 & 0.01 & 0.01 & & \\
\hline $\mathrm{Si}(\mathrm{OH})_{4}$ & nd & nd & nd & nd & & \\
\hline \multicolumn{7}{|l|}{ BioII-96 } \\
\hline $\mathrm{PO}_{4}$ & 0.01 & 0.02 & 0.01 & 0.02 & & \\
\hline $\mathrm{Si}(\mathrm{OH})_{4}$ & nd & nd & nd & nd & & \\
\hline BioI-97 & & & $(+\mathrm{EDTA})$ & $(+$ EDTA $)$ & & \\
\hline $\mathrm{PO}_{4}$ & 0.10 & 0.10 & 0.11 & 0.11 & & \\
\hline $\mathrm{Si}(\mathrm{OH})_{4}$ & 0.00 & 0.00 & 0.00 & 0.00 & & \\
\hline \multicolumn{7}{|l|}{ BioII-97 } \\
\hline $\mathrm{PO}_{4}$ & 0.00 & 0.00 & & & 0.02 & 0.15 \\
\hline $\mathrm{Si}(\mathrm{OH})_{4}$ & 0.01 & 0.02 & & & 0.02 & 0.05 \\
\hline \multicolumn{7}{|l|}{ BioIII-97 } \\
\hline $\mathrm{PO}_{4}$ & 0.00 & 0.00 & & & 0.09 & 0.15 \\
\hline $\mathrm{Si}(\mathrm{OH})_{4}$ & 0.00 & 0.00 & & & 0.00 & 0.00 \\
\hline
\end{tabular}


pelago; Delesalle unpubl. data), but the mechanism which triggered these blooms is unknown. The present study provides the first experimental evidence that diatom outbursts observed in some lagoons of Polynesian atolls may be caused by a combined supply of $\mathrm{N}$ and $P$.

The addition of a single major nutrient ( $\mathrm{N}$ or $\mathrm{P}$ ) without the other was, in most cases, insufficient to enhance the algal biomass and production. This was especially true for the $+\mathrm{P}$ treatments, which had no significant effect on chl a (Fig. 2c,d), carbon production (Table 3), or cell number (Figs. 5 \& 6d). It is known that, in atoll lagoons, $\mathrm{P}$ is strongly absorbed in the carbonate-rich sediments and the dissolved inorganic $\mathrm{N}: \mathrm{P}$ ratio exceeds 16:1 (Entsch et al. 1983a, CharpyRoubaud et al. 1996). Hence, P availability should ultimately be a limiting factor of algal carbon production in atoll lagoons. Our results show that, under the conditions tested, $\mathrm{P}$ was not the limiting factor, and that $\mathrm{N}$ alone was the most limiting macronutrient. Indeed, in half the experiments (Biol-96 and BioI-97), the addition of $N$ stimulated chl a (Fig. $2 a, b$ ) and the gross rates of algal carbon production (Table 3). The effects of $\mathrm{N}$ alone on phytoplankton were, however, smaller than when $\mathrm{N}$ was combined with $\mathrm{P}$, i.e. the increases of chl $a$ and algal carbon production rates were higher in the $+\mathrm{NP}$ treatments than in the $+\mathrm{N}$ treatments (Fig. 2a,b,e, f, Table 3). Moreover, the abundance of $<3 \mu \mathrm{m}$ algae strongly increased in the +NP treatments but not in the $+\mathrm{N}$ treatments (Fig, 6a,e). Therefore, the addition of $\mathrm{N}$ without $\mathrm{P}$ did not promote a large increase in algal carbon production likely because the low availability of $\mathrm{P}$ rapidly impeded the stimulating effect of $\mathrm{N}$. In atoll lagoons, the availability of a given nutrient in the water column depends on its rate of supply by remineralization and by external input from the sediments, the ocean, and the atmosphere (rain). In the lagoon of Takapoto Atoll, the input from the ocean is very low because of the long residence time of water, and the rain has $\mathrm{N}$ and $\mathrm{P}$ contents similar to the concentrations in the lagoon (data not shown). Hence, the main sources of nutrients are recycling processes and the resuspension of sediments.

The present study is the first to investigate the role of macronutrients in controlling the zooplankton community of an atoll lagoon. Grazers in the incubated samples were only protozooplankton (microscopic observations showed only protozoa), i.e. we never observed metazoan micro- or mesozooplankton. This is because the volume of incubated bottles was relatively small $(2 \mathrm{l})$, and these were filled with surface water at sunrise when most of the metazooplankton had migrated to deeper water (Renon 1989). The dual addition of $\mathrm{N}$ and $\mathrm{P}$ was associated with the highest increase in the rate of protozoan carbon production (Table 3). It is recognized that the biomass and production of grazers depend on both prey quantity and quality (Peters 1984, Hessen 1990). It follows that the increase in the carbon production rate of protozoa observed in the $+N P$ treatments may have been a consequence of the increase in phytoplankton biomass (Figs. 5 \& 6e), and/or a change in the nutritional status of phytoplankton (intracellular $\mathrm{N}$ :P ratio).

As mentioned above, when the 2 major nutrients ( $N$ and $P$ ) were simultaneously added, there were strong increases in the algal abundances (Figs. 5 $\& 6 \mathrm{e}$ ) and rates of carbon production (Fig. 2e, f, Table 3), despite higher grazing rates (Table 3). So, when $\mathrm{N}$ and $\mathrm{P}$ were supplied together, protozoan grazing could not keep up with the enhanced production of algae. The grazers may also contribute to sustaining the algal production by regenerating $\mathrm{N}$ nutrients (i.e ammonium excretion) and thus preventing the retention of $\mathrm{N}$ in the plankton biomass. Ammonium excretion from protozoan grazing, in the +NP treatments, may have been the main factor stimulating the major increases of chl a biomass and cell numbers of small phytoplankton in these treatments (Figs. 2e \& 6e).

\section{Eifects of iron enrichments}

The main primary producers in the lagoon of Takapoto Atoll are picoplanktonic autotrophs (Charpy et al. 1992, Charpy \& Blanchot 1996). Our results suggest that the biomass of small phytoplankton was not severely Fe limited, i.e. neither the abundance of $<3 \mu \mathrm{m}$ cells (Fig. 6b) nor the $<3 \mu \mathrm{m}$ chl a (Fig. 3a) responded to the addition of $\mathrm{Fe}$. In contrast, our results show possible limitation of the eucaryotic algal biomass by $\mathrm{Fe}$. In the Biol- -97 experiment, the $>3 \mu \mathrm{m}$ chl a (Fig. 3b), the abundance of large algae (Fig. 4c,d), and the contribution of eucaryotes to the $<3 \mu \mathrm{m}$ algal carbon biomass (Table 4) significantly increased relative to the controls in the $+\mathrm{Fe}$ treatment. Increases of algal biomasses sometimes occurred in the controls, but these cannot be interpreted as reflecting $\mathrm{Fe}$ contamination. Firstly, we were very careful in collecting the samples and doing enrichments (see 'Methods'). Secondly, changes in algal biomass reflect the balance between growth and grazing, i.e. if grazing is less than growth, then net accumulation of algal biomass in a control may occur. In the BioI-97 experiment, the rates of algal carbon production were stimulated by the addition of both $\mathrm{Fe}$ alone and in combination with $\mathrm{N}$ (Table 3). The above results support our second hypothesis, i.e. in the one experiment where Fe stimulated the algal biomass, the effect concerned the large 
phytoplankton. To our knowledge, this is the first report of possible Fe limitation of phytoplankton biomass in an atoll lagoon. Our finding is contrary to the study of Dufour \& Berland (1999), who found no response of the in vivo chl a fluorescence to Fe enrichment in 10 lagoons of the Tuamotu Archipelago,

In our experiments, Fe stimulation of algal carbon production was only observed during Biol-97 In that experiment, the added Fe was complexed with EDTA to ensure that it remained in solution. Since EDTA additions by themselves had no effect on phytoplankton in other Tuamotu Atoll lagoons (Dufour \& Berland 1999), we consider that the stimulating effect by FeEDTA in 1997 was due to Fe. The lack of a stimulating effect from Fe addition in 1996 may reflect natural variation in the availability of this resource between the 2 years.

The main taxonomic groups of $>3 \mu \mathrm{m}$ phytoplankton, i.e. chlorophyceae, dinoflagellates, and coccolithophores, responded positively to the Fe addition (Fig. 4c,d). Previous studies demonstrated a response of diatoms to Fe enrichments (Coale 1991, DiTullio et al. 1993, Boyd et al. 1996, Sedwick \& DiTullio 1997). In our Fe enrichment study, there was no response of diatoms, which may have been primarily limited by Si (see above). Our experiments show that Fe especially limited the abundance of coccolithophores, since in the + Fe treatment, these displayed the highest increase among algal groups (Fig. 4c,d). The coccolithophore assemblage of the Takapoto lagoon is generally dominated by Syracosphaera spp. (data not shown) but, in the $+\mathrm{Fe}$ enrichment, the coccolithophores were dominated by Acanthoica sp. It follows that the addition of Fe may have a major effect on the taxonomic composition of algae in the Takapoto lagoon.

As observed for large algae, the +Fe treatment enhanced the carbon production rate of protozoa (Biol-97; Table 3). The increase in protozoan biomass could be due to the increase in algal food availability. In addition, the Fe intracellular content of phytoplankton may have been enhanced by the + Fe treatment, which could have contributed to the increased protozoan carbon production. This would be consistent with the results of Chase \& Price (1997), who recently showed in laboratory experiments that 2 protozoan species grew at maximum rates only when they fed upon iron-rich bacterial prey. The above results indicate that $\mathrm{Fe}$ availability was a factor that controlled the protozooplankton assemblage in the lagoon of Takapoto Atoll.

The increased grazing rates in the +Fe treatment (Table 3) may have led to increased Fe regeneration by grazers. This would have contributed to sustaining the high algal biomass by ensuring that $F e$ was not retained in biomasses. The significance of Fe recycling via protozoan grazing, in supporting phytoplankton growth, was previously suspected (Hutchins et al. 1993, Hutchins \& Bruland 1994). Landry et al. (1997) recently showed that total production of phytoplankton in the Central Equatorial Pacific depends on efficient iron recycling by grazers.

\section{Overall nutrient effects}

The present study is the first investigation of limitation of the phytoplankton assemblage by major nutrients and $\mathrm{Fe}$ in an atoll lagoon. Our results indicate that $\mathrm{N}$ alone could promote high algal biomasses, but that combination with $\mathrm{P}$ could lead to higher increases of algal biomass and carbon production. Hence, $N$ and $P$ together potentially limited the biomass and carbon production of both small and large algae. A sudden supply of these nutrients to the lagoon, for example following sediment resuspension by wind, may change the taxonomic composition of the $>3 \mu \mathrm{m}$ algal population and trigger a phytoplankton outburst. Fe could also limit the biomass of $>3 \mu \mathrm{m}$ algae, especially coccolithophores. Since no diatom response was observed in the Fe enrichment bioassays and only weakly silicified diatoms sometimes grew following addition of macronutrients, these algae were likely Si limited. The production and grazing rates of protozooplankton were indirectly controlled by NP and Fe availability. Since protozoa are the main link between algal production and higher trophic levels, the nutrient control of protozoa may be significant for the fate of primary production in atoll lagoons.

Acknowledgements. This research was carried out in French Polynesia with the financial support of EVAAM (Etablissement pour la Valorisation des Activités Aquacoles et Maritimes) and NSERC (Natural Sciences and Engineering Research Council of Canada). We express our gratitude to the director of the EVAAM station in the Takapoto Atoll, G. Haumani, and his team for efficient assistance in the field. We thank N. Niquil for help in the field, M. Mallein for laboratory assistance, and C. Lovejoy for useful comments. This is a contribution to the research programme of GIROQ (Groupe interuniversitaire de recherches océanographiques du Québec).

\section{LITERATURE CITED}

Andrefouët $S$ (1994) Caractérisation des éléments morphologiques des atolls des Tuamotu à partir des données SPOT Mémoire de DEA, Université française du Pacifique, Papeete

Behrenfeld MJ, Bale AJ, Kolber ZS, Aiken J, Falkowski PG (1996) Confirmation of iron limitation of phytoplankton photosynthesis in the Equatorial Pacific Ocean. Nature 383:508-51:

Booth B (1988) Size classes and major taxonomic groups of phytoplankon at two locations in the subarctic Pacific Ocean in May and August 1984. Mar Biol 97:275-286 
Boyd PW, Mugqli. DL, Varela DE, Chrétien R, Goldblatt RH, Orians KJ, Harrison PJ (1996) In vitro iron enrichment and herbivory experiments in the NE subarctic Pacific. Mar Ecol Prog Ser 136:179-193

Brown CM. Trick CG (1992) Responses of the cyanobacterium, Oscillatoria tenuis, to low iron environments: the effect on growth rate and evidence for siderophore production. Arch Microbiol 157:349-354

Carpenter EJ (1983) Nitrogen fixation by marine Oscillatoria (Trichodesmium) in the World's Ocean. In: Carpenter EJ, Capone DG (eds) Nitrogen in marine environment Academic Press, New York, p 65-104

Charpy L (1996) Phytoplankton biomass and production in two Tuamotu atoll lagoons (French Polynesia). Mar Ecol Prog Ser 145:133-142

Charpy L, Blanchot J (1996) Prochlorococcus contribution to phytoplankton biomass and production of Takapoto Atoll (Tuamotu Archipelago). C R Acad Sci 319:13-17

Charpy L, Blanchot J, Lo L (1992) Contribution des cyanobactéries (Synechococcus spp.) à la production phytoplanctonique dans un lagon d'atoll fermé (Takapoto, Tuamotu, Polynésie Française). C R Acad Sci 314:395-401

Charpy-Roubaud C, Charpy L, Sarazin G (1996) Diffusional nutrient fluxes at sediment-water interface and organic matter mineralization in an atoll lagoon (Tikehau, Tuamotu Archipelago, French Polynesia). Mar Ecol Prog Ser 132:181-190

Charpy-Roubaud C, Charpy L, Larkum AW (1997) Contribution of $\mathrm{N}_{2}$ fixation to $\mathrm{N}$ primary productivity of the lagoon of Tikehau. In: Lessios HA (ed) 8th Coral Reef Symp, 1, Panama. Allen Press, New York, p 803-808

Chase Z, Price NM (1997) Metabolic consequences of iron deficiency in heterotrophic marine protozoa. Limnol Oceanogr 42:1673-1684

Coale KH (1991) Effects of iron, manganese, copper and zinc enrichments on productivity and biomass in the subarctic Pacific. Limnol Oceanogr 36:1851-1864

Cullen JJ, Lewis MR, Davis CO, Barber RT (1992) Photosynthetic characteristics and estimated growth rates indicate grazing is the proximate control of primary production in the equatorial Pacific. J Geophys Res 97:639-654

de Baar HJW, de Jong JTM, Loscher BM, Bathmann U (1995) Importance of iron for plankton blooms and carbon dioxide drawdown in the Southern Ocean. Nature 373: 412-415

DiTullio GR, Hutchins DA, Bruland KW (1993) Interaction of iron and major nutrients controls phytoplankton growth and species composition in the tropical North Pacific Ocean. Limnol Oceanogr 38:495-508

Dufour P, Berland B (1999) Nutrient control of phytoplanktonic biomass in atoll lagoons and Pacific Ocean waters: studies with factorial enrichment bioassays. J Exp Mar. Biol Ecol 234:147-166

Dugdale RC. Goering JJ (1967) Uptake of new and regenerated forms of nitrogen in primary productivity. Limnol Oceanogr 12:196-206

Dugdale RC, Wilkerson F (1992) Nutrient limitation of new production in the sea. In: Falkowski PG, Woodhead AD (eds) Primary productivity and biogeochemical cycles in the sea. Plenum, New York, p 107-122

Entsch B, Boto KG, Sim RG, Wellington JT (1983a) Phosphorus and nitrogen in coral reef sediments. Limnol Oceanogr 28:465-476

Entsch B, Sim RG, Hatcher BG (1983b) Indications from photosynthetic components that iron is a limiting nutrient in primary producers on coral reefs. Mar Biol 73:17-30

Goldman JC, Dennett MR (1985) Susceptibility of some marine phytoplankton species to cell breakage during filtration and post-filtration rinsing. J Exp Mar Biol Ecol 86 $47-58$

Graziano LM, Geider RJ, Li WKW, Olaizola M (1996) Nitrogen limitation of North Atlantic phytoplankton: analysis of physiological condition in nutrient enrichment experiments. Aquat Microb Ecol 11:53-64

Hall JA (1991) Long-term preservation of picophytoplankton for counting by fluorescence microscopy. J Phycol 26 $169-174$

Heckey RE, Kilham P (1988) Nutrient limitation of phytoplankton in freshwater and marine environments: a review of recent evidence on the effects of enrichment. Limnol Oceanogr 33:796-822

Henley WJ, Yin Y (1998) Growth and photosynthesis of marine Synechococcus (Cyanophyceae) under iron stress. J Phycol 34:94-103

Hessen DO (1990) Carbon, nitrogen and phosphorus status in Daphnia at varying food conditions. J Plankton Res 12 1239-1249

Hutchins DA, Bruland KW (1994) Grazer-mediated regeneration and assimilation of $\mathrm{Fe}, \mathrm{Zn}$ and $\mathrm{Mn}$ from planktonic prey. Mar Ecol Prog Ser 110:254-269

Hutchins DA, Rueter JG, Fish W (1991) Siderophore production and nitrogen fixation are mutually exclusive strategies in Anabaena 7120. Limnol Oceanogr 36:1-12

Hutchins DA, DiTullio GR, Bruland KW (1993) Iron and regenerated production: evidence for biological iron recycling in two marine environments. Limnol Oceanogr 38 : $1242-1255$

Kana TM, Glibert PM (1987) Effect of irradiance up to $2000 \mu \mathrm{E} \mathrm{m} \mathrm{m}^{-2} \mathrm{~s}^{-1}$ on marine Synechococcus WH7803-I. Growth, pigmentation and cell composition, Deep-Sea Res 34:479-516

Kinsey DW, Domm A (1974) Effects of fertilisation on a coral reef environment-primary production studies. In: Cameron AM, Campbell BM, Cribb AB, Endean R, Jell JS, Jones OA, Mather P, Talbot FH (eds) 2nd Coral Reef Symp, 1, Brisbane. The Great Barrier Reef Committee Brisbane, $p$ 49-66

Landry MR, Berber RT, Bidigare RR, Chai F, Coale KH, Dam HG, Lewis MR, Lindley ST, McCarthy JJ, Roman MR, Stoecker DK, Verity PG, White JR (1997) Iron and grazing constraints on primary production in central equatorial Pacific: an EqPac synthesis. Limnol Oceanogr 42:405-418

Larkum AWD, Koop K (1997) Algal productivity and possible paradigm shifts. In: Lessios HA (ed) 8th Coral Reef Symp 1. Panama. Allen Press, New York, p 881-884

Laws EA, Allen CB (1996) Water quality in a subtropical embayment more than a decade after diversion of sewage discharges. Pac Sci 50:194-210

Lindley ST, Barber RT (1998) Phytoplankton response to natural and experimental iron addition. Deep-Sea Res (II) 45 : $1135-1.150$

Lund JWG, Kipling C, LeCren ED (1958) The inverted microscope method of estimating algal numbers and statistical basis of estimations by counting. Hydrobiologia 11 : $143-170$

Maclsaac EA, Stockner JG (1993) Enumeration of phototrophic picoplankton by autofluorescence microscopy. In: Kemp PF, Sherr BF, Sherr EB, Cole JJ (eds) Handbook of methodology in aquatic microbial ecology. Lewis Publishers, Boca Raton, FL, p 187-197

Martin JH and 43 others (1994) Testing the iron hypothesis in ecosystems of the equatorial Pacific Ocean. Nature 371: $123-129$

Parsons TR, Maita Y, Lalli CM (1984) A manual of chemical 
and biological methods for seawater analysis. Pergamon Press, Toronto

Peters RH (1984) Methods for the study of feeding, grazing and assimilation by zooplankton. In: Downing JA. Rigler $\mathrm{FH}$ (eds) A manual on methods for the assessment of secondary productivity in fresh waters. IBP Handbook 17 Blackwell Scientific, Oxford, p 336-412

Price NM, Morel FMM (1998) Biological cycling of iron in the ocean. In: Sigel A, Sigel H (eds) Metal ions in biological systems, Vol 35. Iron transport and storage in microorganisms, plants, and animals, Marcel Dekker, New York, p 1-36

Price NM, Harrison GI, Hudson RJ, Nirel PMV, Palenik B Morel FMM (1989) Preparation and chemistry of artificial algal culture medium Aquil. Biol Oceanogr 6:443-461

Price NM, Ahner BA, Morel FMM (1994) The equatorial Pacific: grazer controlled phytoplankton population in an iron-limited ecosystem. Limnol Oceanogr 39:520-534

Putt M, Stoecker DK (1989) An experimentally determined carbon:volume ratio for marine oligotrichous ciliates from estuarine and coastal waters. Limnol Oceanogr 34: $1097-1103$

Rassoulzadegan $\mathrm{F}$ (1982) Feeding in marine planktonic proto20a. Ann Inst Océanogr Paris 58:191-206

Redfield AC, Ketchum BH, Richards FA (1963) The influence of organisms on the composition of sea-water. In: Hill MN (ed) The sea, Vol 2. Wiley, New York, p 26-77

Renon JP (1989) Le zooplancton des milieux recifo-lagunaires de Polynésie: variation temporelles, variations spatiales et bilan de production et d'échanges. PhD thesis, Université d'Orléans

Riegman R, Deboer M, Domis LD (1996) Growth of harmful marine algae in multispecies cultures. J Plankton Res 18: $1851-1866$

Editorial responsibility: Fereidoun Rassoulzadegan, Villefranche-sur-Mer, France
Rougerie F (1979) Caractéristiques générales du milieu liquide lagunaire de l'atoll de Takapoto, Tuamotu. J Soc Océanistes 62:35-46

Rueter JG, Ohki K, Fujita Y (1990) The effect of iron nutrition on photosynthesis and nitrogen fixation in cultures of Trichodesmium (Cyanophyceae). J Phycol 26:30-35

Sedwick PN, DiTullio GR (1997) Regulation of algal blooms in Antarctic shelf waters by the release of iron from melting sea ice. Geophys Res Lett 24:2515-2518

Sheldon RW, Nival P, Rassoulzadegan F (1986) An experimental investigation of a flagellate-ciliate-copepod food chain with some observations relevant to the linear biomass hypothesis. Limnol Oceanogr 31:184-188

Smith SV (1984) Phosphorus vs. nitrogen limitation in the marine environment. Limnol Oceanogr 29:1149-1160

Sournia A, Ricard M (1976) Données sur l'hydrologie et la productivité du lagon d'un atoll fermé (Takapoto, Tuamotu). Vie Milieu 26:243-279

Utermöhl H (1931) Neue Wege in der quantitativen Erfassung des Planktons (mit besonderer Berücksichtigung des Ultraplanktons). Verh Int Ver Theor Angew Limnol 5: 567-596

Wells ML, Price NM, Bruland KW (1994) Iron limitation and the cyanobacterium Synechococcus in equatorial Pacific waters. Limnol Oceanogr 39:1481-1486

Wilhelm SW, Trick CG (1994) Iron-limited growth of cyanobacteria: multiple siderophore production is a common response. Limnol Oceanogr 39:1979-1984

Wilhelm SW, Maxwell DP, Trick CG (1996) Growth, iron requirements and siderophore production in iron-limited Synechocaccus PCC 7002. Limnol Oceanogr 41:89-97

Zar JH (1984) Biostatistical analysis. Prentice-Hall, Englewood Cliffs, NJ

Submitted: June 23, 1998; Accepted: March 31, 1999

Proofs received from author(s): September 24, 1999 